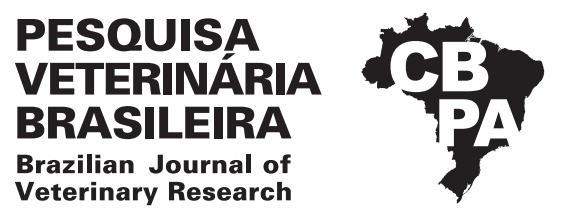

Pesq. Vet. Bras. 39(11):915-922, November 2019 DOI: 10.1590/1678-5150-PVB-6158

Original Article

ISSN 0100-736X (Print) Small Animal Diseases

ISSN 1678-5150 (Online)

\title{
Genotyping of Malassezia pachydermatis disclosed genetic variation in isolates from dogs in Colombia ${ }^{1}$
}

\author{
Adriana Marcela Celis-Ramírez ${ }^{2,3 *}$ (D), Marcela Guevara-Suarez ${ }^{2,3}$, \\ Juan Camilo Galvis-Marín ${ }^{4}$, María Ximena Rodríguez-Bocanegra ${ }^{4}$, \\ Rubiela Castañeda-Salazar ${ }^{4}$, Melva Yomary Linares-Linares ${ }^{4}$, \\ Sergio Heli Triana-Sierra ${ }^{2,3,5}$ and Adriana del Pilar Pulido-Villamarín ${ }^{4 *}$
}

\begin{abstract}
Celis-Ramírez A.M., Guevara-Suarez M., Galvis-Marín J.C., Rodríguez-Bocanegra M.X., Castañeda-Salazar R., Linares-Linares M.Y., Triana-Sierra S.H. \& Pulido-Villamarín A.P. 2019. Genotyping of Malassezia pachydermatis disclosed genetic variation in isolates from dogs in Colombia. Pesquisa Veterinária Brasileira 39(11):915-922. Unidad de Investigaciones Agropecuarias, Departamento de Microbiología, Facultad de Ciencias, Pontificia Universidad Javeriana, Carrera 7 43-82, Ed. 52, Of. 608, Bogotá, Colombia. Departamento de Ciencias Biológicas, Universidad de Los Andes, Carrera 1 18A-10, Bloque J, Of. J-214, Bogotá, Colombia. E-mails: adriana.pulido@javeriana.edu.co, acelis@uniandes.edu.co

Malassezia pachydermatis is a lipophilic and lipid-dependent yeast mostly isolated from animals' skin; hence, it is regarded as a zoophilic species causing otitis externa in dogs. Aspects associated with its epidemiology and pathogenicity is a matter of interest. This study aimed to conduct a molecular characterization of 43 isolates of M. pachydermatis obtained from dogs with otitis externa. For this purpose, the $5.8 \mathrm{~S}$ internal transcribed spacer 2 (ITS2) and D1/D2 26S rRNA regions were amplified, sequenced and analyzed using restriction fragment length polymorphism (RFLP) with AluI, CfoI, and BstF5I endonucleases. Phylogenetic analyses revealed that these isolates grouped with the sequence types I, IV and V, previously proposed for M. pachydermatis. Interestingly, we found a new polymorphic RFLP pattern using BstF5I, these isolates were associated with the sequence types IV and V, nevertheless an association between polymorphic RFLP patterns, and fosfolipase activity or canine population data was not observed. These findings underline the genetic diversity of M. pachydermatis and provide new insights about the epidemiology of this species in the analyzed population.
\end{abstract}

INDEX TERMS: Genotype, Malassezia pachydermatis, genetic variation, isolates, dogs, Colombia, gene, otitis, PCR-RFLP, sequence types.

RESUMO.- [Genotipagem de Malassezia pachydermatis revelou variação genética em isolados de cães na Colômbia]. Malassezia pachydermatis é uma levedura lipofílica e dependente

\footnotetext{
${ }^{1}$ Received on April 24, 2019.

Accepted of publication on May 7, 2019.

${ }^{2}$ Grupo de Investigación Celulary Molecular de Microorganismos Patógenos (CeMoP), Departamento de Ciencias Biológicas, Universidad de Los Andes, Carrera 1 18A-10, Bloque M, Of. M-201, Bogotá, Colombia.

${ }^{3}$ Laboratorio de Micología y Fitopatología (LAMFU), Universidad de Los Andes, Carrera 118A-10, Bloque J, Of. J-214, Bogotá, Colombia. *Corresponding author: acelis@uniandes.edu.co

${ }^{4}$ Unidad de Investigaciones Agropecuarias (UNIDIA), Departamento de Microbiología, Facultad de Ciencias, Pontificia Universidad Javeriana, Carrera 7 43-82, Ed. 52, Of. 608, Bogotá, Colombia. ${ }^{*}$ Corresponding author: adriana.pulido@javeriana.edu.co

${ }^{5}$ Structural and Computational Biology Unit, European Molecular Biology Laboratory, Meyerhofstraße 1, 69117, Heidelberg, Germany.
}

de lipídios, principalmente da pele de animais. Sendo, por essa razão, considerada uma espécie zoofílica e causadora de otite externa em cães. Neste sentido, aspectos associados à sua epidemiologia e patogenicidade constituem um tema de interesse científico. 0 objetivo deste estudo foi realizar a caracterização molecular de 43 isolados de M. pachydermatis obtidos a partir de cães com otite externa. Para esta propósito, foram amplificadas, sequenciadas e analisadas com enzimas de restrição as regiões do gene 5.8S, do espaçador interno transcrito 2 (ITS2) e D1/D2 do 26S do rRNA pelo método RFLP, com as endonucleases AluI, CfOI e BstF5I. Análises filogenéticas revelaram que os isolados se agruparam com as sequências tipo I, IV e V de M. pachydermatis como já descrito anteriormente. De maneira interessante, se observou um novo RFLP polimórfico utilizando BstF5I. Os isolados que mostraram esse padrão foram associados com os padrões IV e V. No entanto, não foi observada associação entre padrões 
polimórficos de RFLP e atividade de fosfolipase ou dados da população canina. Estes resultados demonstram a diversidade genética de M. pachydermatis e fornecem novas perspectivas sobre a epidemiologia destas espécies na população analisada.

TERMOS DE INDEXAÇÃO: Genotipagem, Malassezia pachydermatis, variação genética, isolados, cães, Colômbia, genes, otite, PCR-RFLP, tipos de sequência.

\section{INTRODUCTION}

Malassezia genus comprises 18 species (Triana et al. 2015, Wu et al. 2015, Cabañes et al. 2016, Honnavar et al. 2016, Lorch et al. 2018), which are considered as the dominant species within animal and human skin mycobiota, characterized by being lipophilic and lipid dependent. Nevertheless, these commensal yeasts have also been related to several dermatological diseases (Sugita et al. 2010, Harada et al. 2015, Wu et al. 2015, Prohic et al. 2016).

Malassezia pachydermatis is one of the most common species within this genus, which is commonly isolated from mammals and birds. In dogs, it is frequently found in the external ear canal; moreover, this species may cause otitis externa and dermatitis (chronic, localized or generalized, external lesions) (Crespo et al. 2002, Bond et al. 2010, Pulido et al. 2010, Pulido-Villamarín et al. 2015). Furthermore, M. pachydermatis has been considered to be potentially zoonotic, mainly associated to fungaemia (Gueho et al. 1987, Morris et al. 2005, Bond et al. 2010, Seyedmousavi et al. 2015). Given the fact that a possible association of genotypes with specific hosts has been discerned, it can be suggested that M. pachydermatis has adapted to their ecological niche and could be related to the establishment of the disease (Puig et al. 2016). In addition, several studies have linked the pathogenicity of this species with phospholipase activity, biofilm production and immune response (Cafarchia et al. 2008, Buommino et al. 2016, Hurtado-Suárez et al. 2016).

Several studies have reported the isolation of M. pachydermatis from external ear canal samples of both ill and healthy canines (Bond et al. 1995, Duarte et al. 2001, Masuda et al. 2000, Castellá et al. 2005, Girão et al. 2006, Brito et al. 2007, Bond et al. 2010). In South America, only some reports regarding this matter has been conducted. In Brazil studies including canines and other domestic and wild animals reported the prevalence of $M$. pachydermatis; however, the identification of these isolates were mainly achieved using conventional methods (Duarte et al. 2001, Girão et al. 2006, Brito et al. 2007). Nevertheless, molecular biology techniques, such as restriction fragment length polymorphism (RFLP) and nucleic acid sequencing have become common place procedures. Molecular methods for species identification employ ribosomal DNA genes (rDNA) as diagnostic markers, including the 26S (D1D2-Fw/D1D2) and 5.8S (ITS3/ITS4) subunits (Mirhendi et al. 2005, Gaitanis et al. 2006, Ribeiro do Prado et al. 2007, Cafarchia et al. 2011a, Kim et al. 2015), this genotyping has allowed to identify high intra-species variability in M. pachydermatis with the presence of several sequence types (Guillot et al. 1997, Cafarchia et al. 2007, 2008, 2011b, Puig et al. 2016). These assessments have improved the characterization of these yeast populations to the better knowledge of their epidemiology.

PCR-RFLP is one of the most reliable techniques, usually trough the restriction enzyme digestion of LSU rDNA and ITS regions (Boekhout et al. 1998, Aizawa et al. 1999, Theelen et al.
2001, Gaitanis et al.2002, Celis \& Cepero de García 2005, Mirhendi et al. 2005, González et al. 2009, Sugita et al. 2010, Amado et al. 2013). Nevertheless, other methods such as multi-locus phylogenetic analyses have evinced to be a useful tool to distinguish closely related species. Recently, these analyses showed that $M$. pachydermatis has a high intraspecies variability due to the presence of several sequence types, at least five (I-V) for LSU and eleven (I-XI) for ITS (Puig et al. 2016). Moreover, the combination of LSU, ITS, CHS2 and $\beta$-tubulin gene sequences revealed the presence of fifteen genotypes clustered in two different clades; one clade mainly comprises isolates from dogs, while the other included isolates from other domestic animals such as cats (Puig et al. 2016).

To date, molecular characterization of $M$. pachydermatis isolates from animals in Colombia has not been reported. Therefore, the aim of the present study was to characterize at molecular level a set of isolates of this species obtained from dogs with otitis externa. This study can provide new insights on the genotypes of M. pachydermatis present in canine otitis.

\section{MATERIALS AND METHODS}

Malassezia isolates and growth conditions. A total of 43 isolates of M. pachydermatis from dogs with clinical record of otitis externa from a previous study (Pulido et al. 2010) were included. The isolates were phenotypically characterized, including the evaluation of phospholipase activity (Pulido-Villamarín et al. 2015), preserved in $10 \%$ skin milk at $-70{ }^{\circ} \mathrm{C}$ according to the methods for preservation and storage of Malassezia species (Crespo et al. 2000), and deposited at the microorganism collection from the "Unidad de Investigaciones Agropecuarias" (UNIDIA, Unit of Agricultural Research) of the "Pontificia Universidad Javeriana". In addition, Malassezia strains: M. furfur CBS 7019, M. pachydermatis CBS 1879, M. sympodialis CBS 7222 and M. slooffiae CBS 7956, obtained from the Fungal Biodiversity Center (Westerdijk Institute, Utrecht, The Netherlands), were used as phenotypic and genotypic controls. All strains were recovered using modified Dixon agar (mDixon agar; $36 \mathrm{~g} \mathrm{~L}^{-1}$ Mycosel agar - BD, Franklin Lakes/NJ, USA -, 20g L-1 Ox bile, $36 \mathrm{~g} \mathrm{~L}^{-1}$ malt extract - Oxoid, Basingstoke, UK -, $2 \mathrm{~mL} \mathrm{~L}^{-1}$ glycerol, $2 \mathrm{~mL} \mathrm{~L}^{-1}$ oleic acid, and $10 \mathrm{~mL} \mathrm{~L}^{-1}$ Tween 40), incubating for 4 to 5 days at $33^{\circ} \mathrm{C}$ (Mirhendi et al. 2005).

Molecular characterization. Total DNA was extracted using the fungal and yeast genomic DNA kit (Norgen Biotek, Thorold, ON, Canada), according to the manufacturer's instructions, and then treated with RNase (Sigma, St Louis/MO, USA) at a final concentration of $2 \mathrm{mg} / \mathrm{mL}$ per sample at $37^{\circ} \mathrm{C}$ for 4 hours. The DNA samples were stored at $-20^{\circ} \mathrm{C}$ until further use.

Two nuclear DNA targets were amplified by PCR and sequenced using primers previously reported (González et al. 2009): ITS3/ITS4 for the 5.8s rDNA-ITS2 region, and D1D2-Fw/D1D2 for 26S rDNA region (Table 1). Polymerase chain reaction amplification was carried out in a final volume of $50 \mu \mathrm{L}$, where each reaction contained $45 \mu \mathrm{L}$

Table 1. Forward and reverse primer sequences employed to amplify regions 5.8S rDNA-ITS2 and 26S rDNA

\begin{tabular}{ccc}
\hline & Primer & Forward/reverse \\
\hline 5.8S rDNA-ITS2 region & ITS3 & 5'-GCATCGATGAAGAACGCAGC-3' \\
& ITS4 & 5'-TCCTCCGCTTATTGATATGC-3' \\
26S rDNA region (D1D2) & D1D2-Fw & 5'-TAACAAGGATTCCCCTAGTA-3' \\
& D1D2-Rv & 5'-ATTACGCCAGCATCCTAAG-3'
\end{tabular}

Reference: Mirhendi et al. (2005). 
Table 2. Origin of the Malassezia pachydermatis isolates included in the present study

\begin{tabular}{|c|c|c|c|c|}
\hline \multirow{2}{*}{ Sequence type } & \multirow{2}{*}{ Isolate no. } & \multirow{2}{*}{ Breed } & \multicolumn{2}{|c|}{ GenBank accession numbers } \\
\hline & & & D1/D2 & ITS \\
\hline I & 11 & Labrador & KU757185 & LT962403 \\
\hline $\mathrm{I}$ & 27 & Labrador & KU757188 & LT962406 \\
\hline $\mathrm{I}$ & 35 & Labrador & KU757189 & LT962407 \\
\hline $\mathrm{I}$ & 43 & Labrador & KU757194 & LT962411 \\
\hline $\mathrm{I}$ & 58 & Labrador & KU757199 & LT962415 \\
\hline $\mathrm{I}$ & 80 & Labrador & KU757203 & - \\
\hline $\mathrm{I}$ & 100 & Labrador & KU757207 & LT962422 \\
\hline $\mathrm{I}$ & 103 & Labrador & KU757209 & LT962424 \\
\hline $\mathrm{I}$ & 104 & Labrador & KU757210 & LT962425 \\
\hline $\mathrm{I}$ & 109 & Labrador & KU757212 & LT962427 \\
\hline $\mathrm{I}$ & 128 & Labrador & KU757220 & LT962432 \\
\hline $\mathrm{I}$ & 129 & Labrador & KU757221 & LT962433 \\
\hline $\mathrm{I}$ & 131 & Labrador & KU757222 & LT962434 \\
\hline $\mathrm{I}$ & 134 & Labrador & KU757223 & LT962435 \\
\hline I & 135 & Labrador & KU757224 & LT962436 \\
\hline I & 141 & Labrador & KU757226 & LT962438 \\
\hline $\mathrm{I}$ & 149 & Labrador & KU757231 & LT962440 \\
\hline I & 153 & Labrador & KU757232 & LT962441 \\
\hline IV & 18 & Labrador & KU757187 & LT962405 \\
\hline IV & 40 & Labrador & KU757193 & LT962410 \\
\hline IV & 65 & Labrador & KU757201 & LT962417 \\
\hline IV & 70 & Golden Retriever & KU757202 & LT962418 \\
\hline IV & 83 & Labrador & KU757205 & LT962420 \\
\hline IV & 111 & Golden Retriever & KU757213 & LT962428 \\
\hline IV & 115 & Stray dog & KU757214 & LT962429 \\
\hline $\mathrm{V}$ & 15 & Labrador & KU757186 & LT962404 \\
\hline $\mathrm{V}$ & 36 & Beagle & KU757190 & LT962408 \\
\hline $\mathrm{V}$ & 38 & Golden Retriever & KU757191 & LT962409 \\
\hline $\mathrm{V}$ & 39 & Golden Retriever & KU757192 & - \\
\hline $\mathrm{V}$ & 47 & Stray dog & KU757195 & LT962412 \\
\hline $\mathrm{V}$ & 54 & Golden Retriever & KU757197 & - \\
\hline $\mathrm{V}$ & 55 & Beagle & KU757198 & LT962414 \\
\hline $\mathrm{V}$ & 59 & Golden Retriever & KU757200 & LT962416 \\
\hline $\mathrm{V}$ & 81 & Labrador & KU757204 & LT962419 \\
\hline $\mathrm{V}$ & 88 & Golden Retriever & KU757206 & LT962421 \\
\hline $\mathrm{V}$ & 101 & Stray dog & KU757208 & LT962423 \\
\hline $\mathrm{V}$ & 107 & French Poodle & KU757211 & LT962426 \\
\hline $\mathrm{V}$ & 116 & Labrador & KU757215 & LT962430 \\
\hline $\mathrm{V}$ & 125 & French Poodle & KU757219 & LT962431 \\
\hline $\mathrm{V}$ & 140 & Labrador & KU757225 & LT962437 \\
\hline $\mathrm{V}$ & 144 & Golden Retriever & KU757228 & LT962439 \\
\hline $\mathrm{V}$ & 156 & Beagle & KU757233 & LT962442 \\
\hline $\mathrm{V}$ & 157 & Beagle & KU757234 & LT962443 \\
\hline
\end{tabular}

PCR SuperMix (1.1X) (Thermo Scientific, St Peters/MO, USA), $1 \mu \mathrm{L}$ of each primer $(10 \mathrm{pmol} / \mu \mathrm{L})$, and $3 \mu \mathrm{L}$ of genomic DNA $(20 \mathrm{ng} / \mathrm{mL})$. A first analysis with 26S rDNA and ITS sequences using the nucleotide BLAST tool ${ }^{6}$ was carried out to confirm the preliminary phenotypic identification. The amplification protocol consisted of an initial denaturation step for $5 \mathrm{~min}$ at $95^{\circ} \mathrm{C}$ and 30 cycles consisting of $95^{\circ} \mathrm{C}$ for $1 \mathrm{~min}, 55^{\circ} \mathrm{C}$ for $1 \mathrm{~min}$, and $72^{\circ} \mathrm{C}$ for $1 \mathrm{~min}$, followed by a final $5 \mathrm{~min}$ extension step at $72^{\circ} \mathrm{C}$

The restriction enzyme digestion for the amplicon of 5.8S region was done with AluI (Thermo Scientific, St Peters/MO, USA) and for $26 \mathrm{~S}$ region with $C f o$ I (Promega, Madison/WI, USA) and BstF5I (Thermo

6 Basic Local Alignment Search Tool. Available at $<$ https://blast.ncbi.nlm.nih. gov/Blast.cgi>
Scientific, St Peters/MO, USA), enzyme reactions were performed as previously reported (Mirhendi et al. 2005). The products were visualized in $1.8 \%(\mathrm{p} / \mathrm{v})$ agarose gel electrophoresis using a Gel Doc System (Bio-Rad, Hercules/CA, USA).

Single-band PCR products were purified and sequenced using an ABI3730xl DNA analyzer (Applied Biosystems, Foster City/CA, USA). Consensus sequences were assembled using Geneious software v.4.8.57. DNA sequences determined in this study have been deposited in GenBank, the accession numbers are reported in Table 2.

Phylogenetic reconstructions. In order to assess the intraspecific variability of our isolates, we performed phylogenetic analyses using

\footnotetext{
7 Geneious Bioinformatics Software for Sequence Data Analysis. Available at $<$ http://www.geneious.com>
} 
the sequences data of D1/D2 and ITS and complemented them with sequence types reported for M. pachydermatis retrieved from GenBank database (Puig et al. 2016). Additionally, sequences of type strains of Malassezia species were included. For phylogenetic analyses, sequences of the individual loci were aligned using ClustalW algorithm (Thompson et al. 1994) in MEGA v. 7.0 (Kumar et al. 2016), refined with MUSCLE (Edgar 2004), and manually adjusted using the same software platform. Phylogenetic reconstructions were made with the individual loci using maximum-likelihood (ML) in MEGA v. 7.0 and Bayesian inference (BI) under MrBayes v. 3.1.2 (Huelsenbeck \& Ronquist 2001). The best substitution model for all matrices was estimated using JModelTest v. 2.1 (Darriba et al. 2012). For ML analyses, nearest-neighbor interchange was used as the heuristic method for tree inference. Support for internal branches was assessed by 1,000 ML bootstrapped pseudoreplicates of data. The phylogenetic reconstruction by BI was performed using 1,000,000 Markov chain Monte Carlo (MCMC) generations, with two runs (one cold chain and three heated chains), and samples were stored every 1,000 generations. The 50\% majority-rule consensus tree and posterior probability (pp) values were calculated after discarding the first $25 \%$ of the samples as burn-in. The resulting trees were plotted using FigTree v. 1.4.2 ${ }^{8}$, and edited in Adobe Illustrator CS6. Bootstrap support (bs) and pp values were labelled on nodes of the three. Values of $\geq 70 \mathrm{bs}$ and less than $0.95 \mathrm{pp}$ were considered significant.

In silico restriction. To confirm the restriction pattern for all the sequences obtained from 26S rDNA region with the enzyme BstF5I, in silico digestions were performed using the platform Webcutter $2.0^{9}$.

\section{RESULTS}

For all isolates amplification of the 5.8S rDNA-ITS2 region resulted in a band of $\sim 500 \mathrm{bp}$, and a slightly larger band, $\sim 550 \mathrm{bp}$ was obtained for the $26 \mathrm{~S}$ rDNA region. An analysis with $26 \mathrm{~S} \mathrm{rDNA}$ and ITS sequences using the nucleotide BLAST tool allows us to confirm that all canine isolates were Malassezia pachydermatis. The restriction analysis obtained by PCR-RFLP agreed with what is reported for the identification of $M$. pachydermatis, using the 5.8S rDNA-ITS2 region with AluI, and for 26S rDNA region restriction analysis using $C f o$ I. However, the digestion of $26 \mathrm{~S}$ rDNA region with BstF5I revealed two different restriction patterns. The first pattern was found in 18 out of 43 isolates (Fig.1, lanes 2-4) as well as in the reference strain M. pachydermatis CBS 1879 , this pattern consisted of two bands of $\sim 450$ and $60 \mathrm{bp}$; the second pattern was observed in the remaining isolates $(\mathrm{n}=25)$, this consisted of four bands $\sim 450,300,180$, and 60bp (Fig.1, lanes 5-11). To confirm the new restriction pattern for BstF5I, we performed an in silico restriction, where we observed the results matched with an additional cutting site within the alignment of the $26 \mathrm{~S}$ rDNA region.

Phylogenetic analyses performed to identify sequence types of $M$. pachydermatis based on 26S rDNA are shown in Figure 2. The final alignment with this region was 496bp long, and the model selected was Kimura 2-parameter (K2) with gamma-distributed rates $(\mathrm{G})$. This analysis showed that all canine isolates formed a major clade (97\% bs/1pp) with ex-type strain of M. pachydermatis. Additionally, these isolates

\footnotetext{
8 Figtree Software, Molecular Evolution, Phylogenetics and Epidemiology. Available at $<$ http://tree.bio.ed.ac.uk/software/figtree $>$

9 WebCutter 2.0, A Restriction Mapping Tool. Available at $<$ http://heimanlab. com/cut2.html>
}

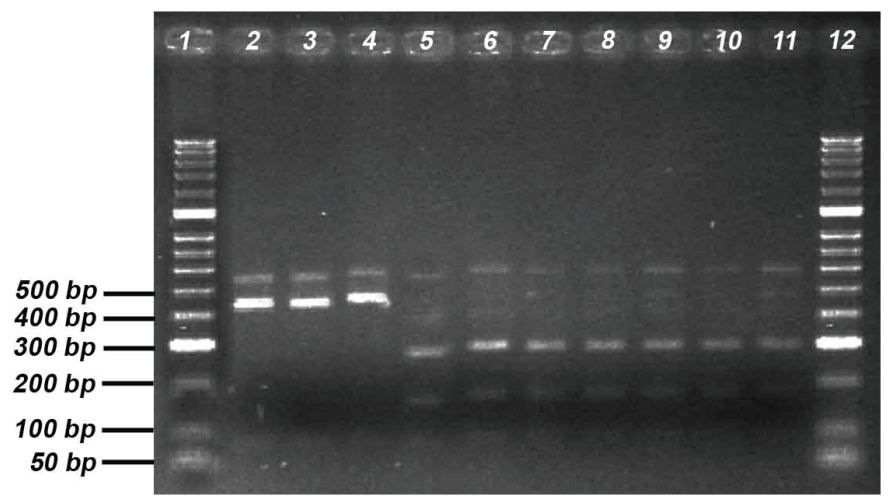

Fig.1. Malassezia pachydermatis 26S rDNA region amplicon digestion with BstF5I. Molecular-weight size marker (lane 1), M. pachydermatis CBS 1879 (lane 2), 26S rDNA region two pattern band ( $\sim 450,60 \mathrm{bp}$ ) with BstF5I (lane 3-4), 26S rDNA region four pattern band $(\sim 450,300,180,60 \mathrm{bp})$ with BstF5I (lane 5-11), molecular-weight size marker (lane 12).

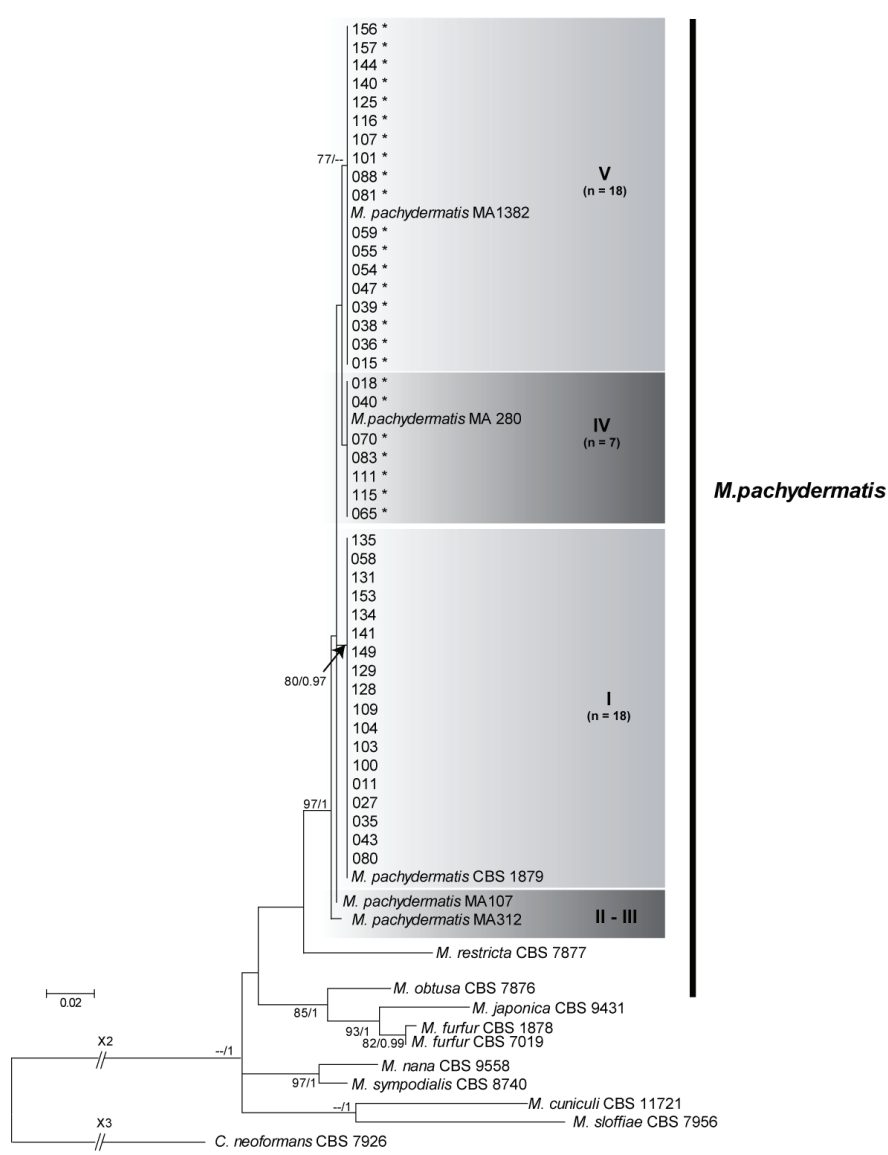

Fig.2. Phylogenetic diversity of isolates of Malassezia pachydermatis obtained from dogs in this study. Phylogenetic tree using maximum-likelihood (ML) and Bayesian inference (BI), tree inferred from 26S rDNA sequence data. Support values are above branches, and represent bootstrap values $>70 \%$ for ML/posterior probabilities $>0.95$ for BI. The tree is rooted to Cryptococcus neoformans CBS 7926. Isolates with the four-banded pattern after digestion with $B s t F 5 I\left({ }^{*}\right)$. The sequences types proposed by Puig et al. (2016) for 26S rDNA region are shown in dark boxes. 


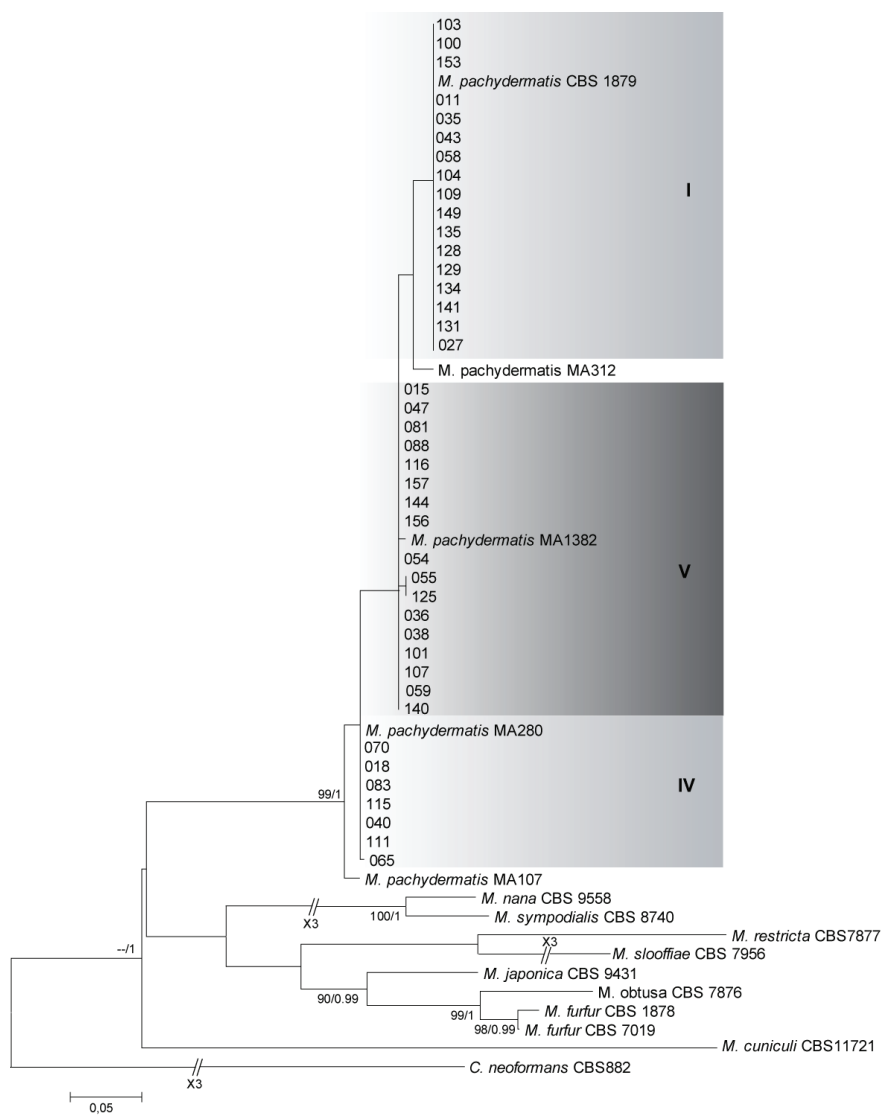

Fig.3. Phylogenetic diversity of isolates of Malassezia pachydermatis obtained from dogs in this study. Phylogenetic tree using maximum-likelihood (ML) and Bayesian inference (BI), tree inferred from 5.8S rDNA-ITS2 region. Support values are above branches, and represent bootstrap values $>70 \%$ for $\mathrm{ML} /$ posterior probabilities $>0.95$ for $\mathrm{BI}$. The tree is rooted to Cryptococcus neoformans CBS 882. The sequence types proposed by Puig et al. (2016) are shown in dark boxes.

were distributed among three sequence types, I $(\mathrm{n}=18)$, IV $(\mathrm{n}=7)$ and $V(\mathrm{n}=18)$, which have been previously reported. The analysis of the ITS sequences (Fig.3) showed similar topology to phylogenetic tree of 26S rDNA region. However, not all clades had a robust phylogenetic support.

Interestingly, we observed that two-banded BstF5I restriction pattern isolates grouped with the sequence type I, while the isolates with the four-banded pattern grouped with the sequence types IV and V (Fig.2). We did not find any association between the BstF5I restriction patterns for $26 \mathrm{~S} \mathrm{rDNA}$ and the phospholipase activity data (previously determined) nor with the breed, age, gender or ear type of the dogs (Pulido et al. 2010, Pulido-Villamarín et al. 2015, Hurtado-Suárez et al. 2016).

\section{DISCUSSION}

This is the first epidemiological study aimed to genotype Malassezia pachydermatis isolates causing canine otitis in Colombia. M. pachydermatis is an important colonizer of healthy canine skin and mucosae; however, it can cause otitis externa and dermatitis (Crespo et al. 2002, Ribeiro do Prado et al. 2007, Cafarchia et al. 2008, Pulido et al. 2010). In humans, this species has been reported in bloodstream infections, possibly caused by zoonotic transmission (Gueho et al. 1987, Morris et al. 2005, Seyedmousavi et al. 2015). The interest in the study of $M$. pachydermatis has increased in the last decades, given the better understanding of aspects regarding its epidemiology and ecology, as well as the unraveling aspects of the pathogenesis and its role in the developing of the diseases. Nevertheless, many aspects are still unknown.

Several molecular typing methods have been previously reported to resolve the species identification discordances between conventional methods, such as morphological and biochemical methods, commonly used for this purpose (Sugita et al. 2010). These advances have been crucial to progress in the diagnostic field. In our study, average size of the amplified 5.8S rDNA-ITS2 region fragment was similar to that reported by Gaitanis et al. (2002), who obtained an average amplicon size of 483bp for M. pachydermatis isolates from dogs lesions diagnosed with otitis. For the 26S rDNA region fragment, our findings agreed with those of Gupta et al. (2004) who reported an average amplicon size of approximately 550bp.

PCR-RFLP is a reliable tool to perform an undemanding identification of Malassezia species, having been widely reported in epidemiological studies in human skin diseases (Gupta 2004, Lee et al. 2006, Jang et al. 2009, Sugita et al. 2010, Sosa et al. 2013, Soares et al. 2015). Through the current study, we were able to identify M. pachydermatis obtained from otitis externa in dogs. The results obtained in our study for the analysis of the restriction patterns of 5.8S rDNA-ITS2 and $26 \mathrm{~S}$ rDNA regions with $A l u \mathrm{I}$ and $C f o \mathrm{I}$, concurred with the previous reports for M. pachydermatis (Mirhendi et al. 2005, González et al. 2009).

The digestion of $26 \mathrm{~S}$ rDNA fragment with BstF5I revealed a dimorphic banding pattern. In previous studies, the only reported banding pattern obtained by BstF5I restriction on M. pachydermatis isolates consisted of two bands of 500 and $70 \mathrm{bp}$ (Mirhendi et al. 2005, González et al. 2009). Remarkably, our results showed a new restriction pattern for the digestion of $26 \mathrm{~S}$ rDNA region with BstF5I, this new pattern consisting of four bands was found in most of the isolates included in this study. The in silico restriction analysis corroborates this finding giving new insights on this species epidemiology in our country. This could be attributed to a genetic variability in the 26S rDNA region for this species and others in this genus, as it has been proposed by several researchers using diverse molecular tools (Aizawa et al. 1999, Cabañes et al. 2005, Cafarchia et al. 2007, 2011a, Duarte \& Hamdan 2010, Wu et al. 2015, Puig et al. 2016). These differences highlight the importance of performing molecular typification for achieving a better identification, and broadening the epidemiological knowledge in animal health (Gupta 2004).

Additionally, different studies have revealed the presence of a high genetic variability into this species with the presence of different genotypes/subgenotypes that can be isolated from domestic and wild animals (Guillot et al. 1997, Cafarchia et al. 2007, 2008, 2011a, Gandra et al. 2008, Álvarez-Pérez et al. 2015, Puig et al. 2016). Here we were able to identify the presence of at least three sequence types (I, IV, V) for M. pachydermatis in D1/D2 and ITS regions. Particularly, the two restriction patterns found for 26S rDNA region with BstF5I were grouped with different sequence types, suggesting a high diversity of this species. These genotypes can be detected in other 
animals such as cats and wild mammals, hence, is important to perform additional analysis including a wide number of isolates from this sources to understand this diversity.

Many other aspects should be explore to have better comprehension about the relation between the presence of this genotypes and a possible connection with the establishment of the disease, such as the relation with bacterial microbiota, $\mathrm{pH}$ and fatty acids composition, aspects that have been linked to the adaptation of this species to some anatomical sites of the host due to the differences found in the lipid metabolism of this yeast (Cafarchia et al. 2008, Buommino et al. 2016, Puig et al. 2016, Triana et al. 2017).

\section{CONCLUSIONS}

The results revealed the presence of different genotypic variants of Malassezia pachydermatis in Colombia.

The existence of different genotypes could be a tool to accurate the clinical management of the species, as well as to understand the ecology and epidemiology of M. pachydermatis and contribute with this data at local and global level.

Acknowledgments.- The authors are grateful to "Vicerrectoría de Investigación" of "Pontificia Universidad Javeriana" for financial support (grant ID: PTA 00004585).

Conflict of interest statement.- All authors declare no conflict of interest.

\section{REFERENCES}

Aizawa T., Kano R., Nakamura Y., Watanabe S. \& Hasegawa A. 1999. Molecular heterogeneity in clinical isolates of Malassezia pachydermatis from dogs. Vet. Microbiol. 70(1/2):67-75. <http://dx.doi.org/10.1016/S03781135(99)00126-1><PMid:10591498>

Álvarez-Pérez S., García M.E., Peláez T. \& Blanco J.L. 2015. Genotyping and antifungal susceptibility testing of multiple Malassezia pachydermatis isolates from otitis and dermatitis cases in pets: is it really worth the effort? Med. Mycol. 54(1):72-79. <PMid:26333353>

Amado Y., Patiño-Uzcátegui A., Cepero De García M.C., Tabima J., Motta A., Cárdenas M., Bernal A., Restrepo S. \& Celis A. 2013. Seborrheic dermatitis: predisposing factors and ITS2 secondary structure for Malassezia phylogenic analysis. Med. Mycol. 51(8):868-875. <http://dx.doi.org/10.3109/13693 786.2013.820001><PMid:23947747>

Boekhout T., Kamp M. \& Guého E. 1998. Molecular typing of Malassezia species with PFGE and RAPD. Med. Mycol. 36(6):365-372. <http://dx.doi. org/10.1080/02681219880000581><PMid:10206745>

Bond R., Saijonmaa-Koulumies L.E.M. \& Lloyd D.H. 1995. Population sizes and frequency of Malassezia pachydermatis at skin and mucosal sites on healthy dogs. J. Small Anim. Pract. 36(4):147-150. <http://dx.doi. org/10.1111/j.1748-5827.1995.tb02865.x><PMid:7603055>

Bond R., Guillot J. \& Cabañes F.J. 2010. Malassezia yeasts in animal disease, p.271-299. In: Boekhout T., Guého-Kellermann E., Mayser P. \& Velegraki A. (Eds), Malassezia and the Skin: science and clinical practice. Springer-Verlag, Berlin, Heidelberg. <http://dx.doi.org/10.1007/978-3-642-03616-3_10>

Brito E.H.S., Fontenelle R.O.S., Brilhante R.S.N., Cordeiro R.A., Soares Júnior F.A., Monteiro A.J., Sidrim J.J.C. \& Rocha M.F.G. 2007. Phenotypic characterization and in vitro antifungal sensitivity of Candida spp. and Malassezia pachydermatis strains from dogs. Vet. J. 174(1):147-153. <http:// dx.doi.org/10.1016/j.tvjl.2006.05.021><PMid:17188535>

Buommino E., Nocera F.P., Parisi A., Rizzo A., Donnarumma G., Mallardo K., Fiorito F., Baroni A. \& De Martino L. 2016. Correlation between genetic variability and virulence factors in clinical strains of Malassezia pachydermatis of animal origin. New Microbiol. 39(3):216-223. <PMid:27284984>

Cabañes F.J., Hernández J.J. \& Castellá G. 2005. Molecular analysis of Malassezia sympodialis-related strains from domestic animals. J. Clin. Microbiol. 43(1):277-283. <http://dx.doi.org/10.1128/JCM.43.1.277-283.2005> $<$ PMid:15634983>

Cabañes F.J., Coutinho S.D.A., Puig L., Bragulat M.R. \& Castellá G. 2016. New lipid-dependent Malassezia species from parrots. Revta Iberoam. Micol. 33(2):92-99. <http://dx.doi.org/10.1016/j.riam.2016.03.003> $<$ PMid:27184440>

Cafarchia C., Gasser R.B., Figueredo L.A., Latrofa M.S. \& Otranto D. 2011a. Advances in the identification of Malassezia. Mol. Cell. Probes 25(1):1-7. <http://dx.doi.org/10.1016/j.mcp.2010.12.003> <PMid:21193026>

Cafarchia C., Latrofa M.S., Figueredo L.A., Silva-Machado M.L., Ferreiro L., Guillot J., Boekhout T. \& Otranto D. 2011b. Physiological and molecular characterization of atypical lipid-dependent Malassezia yeasts from a dog with skin lesions: adaptation to a new host? Med. Mycol. 49(4):365-374. <http://dx.doi.org/10.3109/13693786.2010.531487><PMid:21070187>

Cafarchia C., Gasser R.B., Latrofa M.S., Parisi A., Campbell B.E. \& Otranto D. 2008. Genetic variants of Malassezia pachydermatis from canine skin: body distribution and phospholipase activity. FEMS Yeast Res. 8(3):451-459. <http://dx.doi.org/10.1111/j.1567-1364.2008.00358.x><PMid:18294200>

Cafarchia C., Latrofa M.S., Testini G., Parisi A., Guillot J., Gasser R.B. \& Otranto D. 2007. Molecular characterization of Malassezia isolates from dogs using three distinct genetic markers in nuclear DNA. Mol. Cell. Probes 21(3):229238. <http://dx.doi.org/10.1016/j.mcp.2007.01.002><PMid:17320347>

Castellá G., Hernández J.J. \& Cabañes F.J. 2005. Genetic typing of Malassezia pachydermatis from different domestic animals. Vet. Microbiol. 108(3/4):291296. <http://dx.doi.org/10.1016/j.vetmic.2005.04.016><PMid:15922521>

Celis A.M. \& Cepero de García M.C. 2005. Genetic polymorphism of Malassezia spp. yeast isolates from individuals with and without dermatological lesions. Bioméd. Revta Inst. Nac. Salud 25(4):481-487. <PMid:16433174>

Crespo M.J., Abarca M.L. \& Cabañes F.J. 2000. Evaluation of different preservation and storage methods for Malassezia spp. J. Clin. Microbiol. 38(10):3872-3875. <PMid:11015425>

Crespo M.J., Abarca M.L. \& Cabanes F.J. 2002. Occurrence of Malassezia spp. in the external ear canals of dogs and cats with and without otitis externa. Med. Mycol. 40(2):115-121. <http://dx.doi.org/10.1080/mmy.40.2.115.121> $<$ PMid:12058723>

Darriba D., Taboada G.L., Doallo R. \& Posada D. 2012. jModelTest 2: more models, new heuristics and parallel computing. Nat. Methods 9(8):772. <http://dx.doi.org/10.1038/nmeth.2109><PMid:22847109>

Duarte E.R. \& Hamdan J.S. 2010. RAPD differentiation of Malassezia spp. from cattle, dogs and humans. Mycoses 53(1):48-56. <http://dx.doi. org/10.1111/j.1439-0507.2008.01658.x><PMid:19298360>

Duarte E.R., Resende J.C.P., Rosa C.A. \& Hamdan J.S. 2001. Prevalence of yeasts and mycelial fungi in bovine parasitic otitis in the State of Minas Gerais, Brazil. Zoonoses Publ. Health 48(8):631-635. <PMid:11708682>

Edgar R.C. 2004. MUSCLE: multiple sequence alignment with high accuracy and high throughput. Nucleic Acids Res. 32(5):1792-1797. <http://dx.doi. org/10.1093/nar/gkh340><PMid:15034147>

Gaitanis G., Robert V. \& Velegraki A. 2006. Verifiable single nucleotide polymorphisms of the internal transcribed spacer 2 region for the identification of 11 Malassezia species. J. Dermatol. Sci. 43(3):214-217. <http://dx.doi.org/10.1016/j.jdermsci.2006.03.013><PMid:16797927>

Gaitanis G., Velegraki A., Frangoulis E., Mitroussia A., Tsigonia A., Tzimogianni A., Katsambas A. \& Legakis N.J. 2002. Identification of Malassezia species 
from patient skin scales by PCR-RFLP. Clin. Microbiol. Infect. 8(3):162-173. <http://dx.doi.org/10.1046/j.1469-0691.2002.00383.x><PMid:12010171>

Gandra R.F., Gambale W., Simao R.D.C.G., Silva-Ruiz L., Durigon E.L., Camargo L.M.A., Giudice M.C., Sanfilippo L.F., Araújo J. \& Paula C.R. 2008. Malassezia spp. in acoustic meatus of bats (Molossus molossus) of the Amazon Region, Brazil. Mycopathologia 165(1):21-26. <http://dx.doi.org/10.1007/s11046007-9079-7><PMid:18046623>

Girão M.D., Prado M.R., Brilhante R.S.N., Cordeiro R.A., Monteiro A.J., Sidrim J.J.C. \& Rocha M.F.G. 2006. Malassezia pachydermatis isolated from normal and diseased external ear canals in dogs: a comparative analysis. Vet. J. 172(3):544-548. <http://dx.doi.org/10.1016/j.tvjl.2005.07.004> <PMid:16154787>

González A., Sierra R., Cárdenas M., Grajales A., Restrepo S., Cepero de García M.C. \& Celis A. 2009. Physiological and molecular characterization of atypical isolates of Malassezia furfur. J. Clin. Microbiol. 47(1):48-53. <http://dx.doi. org/10.1128/JCM.01422-08><PMid:18971363>

Gueho E., Simmons R.B., Pruitt W.R., Meyer S.A. \& Ahearn D.G. 1987. Association of Malassezia pachydermatis with systemic infections of humans. J. Clin. Microbiol. 25(9):1789-1790. <PMid:3654952>

Guillot J., Guého E., Chévrier G. \& Chermette R. 1997. Epidemiological analysis of Malassezia pachydermatis isolates by partial sequencing of the large subunit ribosomal RNA. Res. Vet. Sci. 62(1):22-25. <http://dx.doi. org/10.1016/S0034-5288(97)90174-0><PMid:9160419>

Gupta A.K. 2004. Molecular identification of Malassezia species by amplified fragment length polymorphism (AFLP) and sequence analyses of the internal transcribed spacer (ITS) and large subunit (LSU) regions of ribosomal DNA. J. Am. Acad. Dermatol. 50(3):106. <http://dx.doi.org/10.1016/j. jaad.2003.10.351>

Gupta A.K., Boekhout T., Theelen B., Summerbell R. \& Batra R. 2004. Identification and typing of Malassezia species by amplified fragment length polymorphism and sequence analyses of the internal transcribed spacer and large-subunit regions of ribosomal DNA. J. Clin. Microbiol. 42(9):4253-4260.<http://dx.doi.org/10.1128/JCM.42.9.4253-4260.2004> $<$ PMid:15365020>

Harada K., Saito M., Sugita T. \& Tsuboi R. 2015. Malassezia species and their associated skin diseases. J. Dermatol. 42(3):250-257. <http://dx.doi. org/10.1111/1346-8138.12700 > <PMid:25736318>

Honnavar P., Prasad G.S., Ghosh A., Dogra S., Handa S. \& Rudramurthy S.M. 2016. Malassezia arunalokei sp. nov., a novel yeast species isolated from seborrheic dermatitis patients and healthy individuals from India. J. Clin. Microbiol. 54(7):1826-1834.<http://dx.doi.org/10.1128/JCM.00683-16> <PMid:27147721>

Huelsenbeck J.P. \& Ronquist F. 2001. MRBAYES: Bayesian inference of phylogenetic trees. Bioinformatics 17(8):754-755. <http://dx.doi. org/10.1093/bioinformatics/17.8.754><PMid:11524383>

Hurtado-Suárez A., Pulido-Villamarín A., Linares-Linares M., Suárez-Fernández L., Castañeda-Salazar R. \& Rodríguez-Bocanegra M. 2016. Phenotypic characterization of canine Malassezia spp., isolates. Revta MVZ Córdoba 21:5535-5546.

Jang S.-J., Lim S.-H., Ko J.-H., Oh B.-H., Kim S.-M., Song Y.-C., Yim S.-M., Lee Y.-W., Choe Y.-B. \& Ahn K.-J. 2009. The investigation on the distribution of Malassezia yeasts on the normal Korean skin by $26 \mathrm{~S}$ rDNA PCR-RFLP. Ann. Dermatol. 21(1):18-26. <http://dx.doi.org/10.5021/ad.2009.21.1.18> $<$ PMid:20548850>

Kim S.Y., Lee Y.W., Choe Y.B. \& Ahn K.J. 2015. Progress in Malassezia research in Korea. Ann. Dermatol. 27(6):647-657. <http://dx.doi.org/10.5021/ ad.2015.27.6.647><PMid:26719632>
Kumar S., Stecher G. \& Tamura K. 2016. MEGA7: Molecular evolutionary genetics analysis version 7.0 for bigger datasets. Mol. Biol. Evol. 33(7):18701874. <http://dx.doi.org/10.1093/molbev/msw054><PMid:27004904>

Lee Y.W., Lim S.H. \& Ahn K.J. 2006. The application of 26S rDNA PCR-RFLP in the identification and classification of Malassezia yeast. Korean J. Med. Mycol. 11:141-153.

Lorch J.M., Palmer J.M., Vanderwolf K.J., Schmidt K.Z., Verant M.L., Weller T.J. \& Blehert D.S. 2018. Malassezia vespertilionis sp. nov.: a new coldtolerant species of yeast isolated from bats. Persoonia. Mol. Phylog. Evol Fungi 41(1):56-70. <http://dx.doi.org/10.3767/persoonia.2018.41.04> $<$ PMid:30728599>

Masuda A., Sukegawa T., Mizumoto N., Tani H., Miyamoto T., Sasai K. \& Baba E. 2000. Study of lipid in the ear canal in canine otitis externa with Malassezia pachydermatis. J. Vet. Med. Sci. 62(11):1177-1182. <http:// dx.doi.org/10.1292/jvms.62.1177><PMid:11129861>

Mirhendi H., Makimura K., Zomorodian K., Yamada T., Sugita T. \& Yamaguchi H. 2005. A simple PCR-RFLP method for identification and differentiation of 11 Malassezia species. J. Microbiol. Methods 61(2):281-284. <http:// dx.doi.org/10.1016/j.mimet.2004.11.016> <PMid:15722156>

Morris D.O., O'Shea K., Shofer F.S. \& Rankin S. 2005. Malassezia pachydermatis carriage in dog owners. Emerg. Infect. Dis. 11(1):83-88. <http://dx.doi org/10.3201/eid1101.040882> <PMid:15705327>

Prohic A., Jovovic-Sadikovic T., Krupalija-Fazlic M. \& Kuskunovic-Vlahovljak S. 2016. Malassezia species in healthy skin and in dermatological conditions. Int. J. Dermatol. 55(5):494-504. <http://dx.doi.org/10.1111/ijd.13116> <PMid:26710919>

Puig L., Castellá G. \& Cabañes F.J. 2016. Cryptic diversity of Malassezia pachydermatis from healthy and diseased domestic animals. Mycopathologia 181(9/10):681-688. <http://dx.doi.org/10.1007/s11046-016-0026-3> <PMid:27283291>

Pulido A., Castañeda R., Linares M. \& Mercado M. 2010. Diagnóstico clínicomicrobiológico de otitis externa en caninos de Bogotá, Colombia. Revta MVZ Córdoba 15:2215-2222. <http://dx.doi.org/10.21897/rmvz.308>

Pulido-Villamarín A., Castañeda-Salazar R., Linares-Linares M. \& MercadoReyes M. 2015. Concordance between otic cytology and culture in diagnosis of external otitis canine by Malassezia spp. Revta MVZ Córdoba 20:47204725. <http://dx.doi.org/10.21897/rmvz.42>

Ribeiro do Prado M., Nogueira-Brilhante R.S., Costa-Sidrim J.J. \& GadelhaRocha M.F. 2007. Malassezia spp. em humanos e pequenos animais: uma abordagem teórica. Revta Port. Ciênc. Vet. 102:207-214.

Seyedmousavi S., Guillot J., Tolooe A., Verweij P.E. \& De Hoog G.S. 2015. Neglected fungal zoonoses: hidden threats to man and animals. Clin. Microbiol. Infect. 21(5):416-425. <http://dx.doi.org/10.1016/j.cmi.2015.02.031> $<$ PMid:25769429>

Soares R.C., Zani M.B., Arruda A.C.B.B., Arruda L.H.F. \& Paulino L.C. 2015 Malassezia intra-specific diversity and potentially new species in the skin microbiota from Brazilian healthy subjects and seborrheic dermatitis patients. PLoS One 10(2):e0117921. <http://dx.doi.org/10.1371/journal. pone.0117921 ><PMid:25695430>

Sosa M.A., Rojas F., Mangiaterra M. \& Giusiano G. 2013. Prevalence of Malassezia species associated with seborrheic dermatitis lesions in patients in Argentina. Revta Iberoam. Micol. 30(4):239-242. <http:// dx.doi.org/10.1016/j.riam.2013.02.002 > <PMid:23500158>

Sugita T., Boekhout T., Velegraki A., Guillot J., Hadina S. \& Cabañes F.J. 2010 Epidemiology of Malassezia-Related Skin Diseases, p.65-119. In: Boekhout T., Guého-Kellermann E., Mayser P. \& Velegraki A. (Eds), Malassezia and the Skin: science and clinical practice. Springer-Verlag, Berlin, Heidelberg. <http://dx.doi.org/10.1007/978-3-642-03616-3_3> 
Theelen B., Silvestri M., Guého E., Van Belkum A. \& Boekhout T. 2001. Identification and typing of Malassezia yeasts using amplified fragment length polymorphism (AFLP), random amplified polymorphic DNA (RAPD) and denaturing gradient gel electrophoresis (DGGE). FEMS Yeast Res. 1(2):79-86. <http://dx.doi.org/10.1111/j.1567-1364.2001.tb00018.x> <PMid:12702352>

Thompson J.D., Higgins D.G. \& Gibson T.J. 1994. CLUSTAL W: improving the sensitivity of progressive multiple sequence alignment through sequence weighting, position-specific gap penalties and weight matrix choice. Nucleic Acids Res. 22(22):4673-4680. < http://dx.doi.org/10.1093/ nar/22.22.4673> <PMid:7984417>

Triana S., González A., Ohm R.A., Wösten H.A., De Cock H., Restrepo S. \& Celis A. 2015. Draft genome sequence of the animal and human pathogen Malassezia pachydermatis strain CBS 1879. Genome Announc. 3(5):e01197-e15. <http://dx.doi.org/10.1128/genomeA.01197-15><PMid:26472839>

Triana S., De Cock H., Ohm R.A., Danies G., Wösten H.A.B., Restrepo S., GonzálezBarrios A.F. \& Celis A. 2017. Lipid metabolic versatility in Malassezia spp. yeasts studied through metabolic modeling. Front Microbiol. 8:1-18. <http:// dx.doi.org/10.3389/fmicb.2017.01772> <PMid:28959251>

Wu G., Zhao H., Li C., Rajapakse M.P., Wong W.C., Xu J., Saunders C.W., Reeder N.L., Reilman R.A., Scheynius A., Sun S., Billmyre B.R., Li W., Averette A.F., Mieczkowski P., Heitman J., Theelen B., Schröder M.S., De Sessions P.F., Butler G., Maurer-Stroh S., Boekhout T., Nagarajan N. \& Dawson Junior T.L. 2015. Genus-wide comparative genomics of Malassezia delineates its phylogeny, physiology, and niche adaptation on human skin. PLoS Genet. 11(11):e1005614. <http://dx.doi.org/10.1371/journal.pgen.1005614> <PMid:26539826> 